\title{
Variability and Heritability of Sigah Brown Rice Mutants (M3) in Vegetative Phase
} Siska Kurniawati ${ }^{1}$, Irawati Chaniago ${ }^{2}$ and Irfan Suliansyah ${ }^{3}$

\author{
${ }^{1}$ Department of Agronomy, Faculty of Agriculture, Andalas University, Padang, Indonesia \\ E-mail: siskakurniawati22@gmail.com \\ ${ }^{2}$ Associate Professor, Department of Agrotechnology, Faculty of Agriculture, Andalas University, Indonesia \\ ${ }^{3}$ Professor in Plant Physiology, Department of Agrotechnology, Faculty of Agriculture, Andalas University, Indonesia
}

\begin{abstract}
This research aims to obtain information on genetic diversity, variability, and heritability of Sigah brown rice mutants (M3) in the vegetative phase. This research is conducted from March to September 2018 in the irrigation area of Sungai Sapih, Kuranji, Padang, where the area is 48 meters above sea level. The materials used in this study are M2 rice seeds (13 early maturing mutant lines and 10 tall plant mutant lines + number of tillers), and the original plants of Sigah genotype as a comparison (control). The analysis of genetic diversity, heritability, and variability are tested on plant height, number of productive tillers, and percentage of productive tillers. The selection method used in this study found that there are 8 early maturing mutants and 7 tall plant mutants + number of tillers. The line of early maturing mutants number 89 and 76 have wide diversity range in the term of the character of plant height, number of tillers, and number of productive tillers in the vegetative phase. Further, line 4, 19,134 of tall plant mutants + number of tillers have a wide variety of tillers too.
\end{abstract}

Keywords-Variability, heritability, M3 mutants, brown rice

\section{INTRODUCTION}

Indonesia is a wealth paddy country with many variants of rice species in the form of wild species or local cultivars. The Asian continent and Indonesia itself were the centers of rice origin in ancient times. The primary center of rice origin is India, while Indonesia is considered as the secondary center of rice origin. It can also be noted by the existence of many wild species of rice in Indonesia [1].

According to [2] (1993); [3] (2013), local rice cultivars are germplasms that have certain genetic superiority. They have been cultivated continuously making them well-adapted to various specific climatic conditions and land in the planting area. In addition, local rice is naturally tolerant of abiotic stresses, unaffected by pests and diseases, and good in quality. Thus, people who live in a place where they grow, like to eat them.

In general, Indonesian cultivars have superiority in the term of long panicles, round seeds, unfallen seeds, few tillers, photoperiod insensitive, broad leaves, and amylose content. The local varieties, in general, have adapted well to the place or location where the plant is originated. The taste of the rice is also good for the local people and has specific aroma. On the other hand, it has some weaknesses too such as deep and strong rooting but it is not responsive to the provision of fertilizer, deep age, high stems making it easy to fall, and low production. To procure seeds, farmers usually only rely on seeds from their own harvest on an ongoing basis. Thus, the level of seed purity and quality is very low so this affects the harvest. Therefore, the local rice varieties are usually still varied that mainly related to the character of plant height and number of tillers [4].

Plant breeding is an applied science to improve the properties of plants qualitatively and quantitatively. Mendel's law provides a solid basis for the development of plant breeding as a science. A conventional plant breeding is still considered as the main method in improving plant varieties in Indonesia. However, the limited genetic resources used as elders in crossing is an obstacle in conventional plant breeding. The limit of genetic diversity of released rice varieties contributes to the lowering yield potential. Many of the released rice varieties are related to each other, so the diversity is lacking and the yield potential is not different [5].

There are several breeding techniques that can be used to improve the character of plants in a relatively short time period and it can improve one or two characteristics of the plants. One of the techniques is the radiation mutation technique. This mutation technique is used to increase plant genetic diversity. If a character has high genetic diversity, the diversity of characters between individuals in the population will be high too. In this case, the selection will be easier to do to obtain the desired 
traits. The selection method is an effective process for obtaining the desired important traits with a high level of success [6]. This research aims to obtain information on genetic diversity (variability) and heritability of local Sigah brown rice M3 mutants in the vegetative phase.

\section{MATERIALS AND METHODS}

\subsection{Implementation Research}

This research was conducted for seven months, from March to September 2018, which was located in the irrigation area of Sungai Sapih, Kuranji, Padang, where the area was 48 meters above sea level. The materials used in this study were rice seeds from M2 plant selection (13 early maturing mutant lines and 10 tall plant mutant lines + number of tillers), the original plants from Sigah genotype as a comparison (control), urea fertilizer, SP36, $\mathrm{KCl}$, and pesticides for plant care from pest and disease attacks and other materials used during plant care. Tools used were hoes and tractors for land management, waring, spraying pests and plant diseases, weeding, and observation aids.

\subsection{Data analysis}

Then, the analysis of genetic diversity, heritability, and variability of plant height, number of productive tillers, and the percentage of productive tillers was done after the selection of M3 mutant plants. The phenotype variance score was obtained from observing 15 mutant plants in each line. Next, the variety of environments was obtained by taking Sigah samples of 15 control plants. Further, the genetic variance was obtained by subtracting the diversity of phenotypes and environmental variations. Furthermore, the heritability and variability scores in each plant were calculated. The genetic heritability and variability were calculated using the following formula:

$$
\sigma^{2}=\frac{\left(\sum x 2\right)-\left[\left(\sum X\right) 2 / n\right]}{\mathrm{n}-1}
$$

Where :

$$
\begin{aligned}
& \sigma^{2}=\text { Variety } \\
& n=\text { Total population } \\
& \sigma^{2} p=\text { Variety of phenotypes } \\
& \sigma^{2} g=\text { Variety of genotypes } \\
& \sigma^{2} \text { e }=\text { Variety of Environments }
\end{aligned}
$$

The heritability score:

$$
H^{2}{ }_{b s}=\frac{\sigma^{2} g}{\sigma_{p}^{2}}
$$

The heritability convention : low (hbs $\leq 0,2)$, moderate $\left(0,2 \leq \mathrm{h}^{2}{ }_{\mathrm{bs}} \leq 0,5\right)$, and height (hbs $\left.\left.>0,5\right)\right)$.

\section{RESULTS AND DISCUSSIOND}

3.1 The vegetative variables (plant height, the total number of tillers, and number of productive tillers)
Dari hasil seleksi yang telah dilakukan diperoleh (8 galur mutan genjah dan 5 galur mutan tinggi tanaman + jumlah anakan) terdapat variasi antara peubah vegetatif (tinggi tanaman, jumlah anakan total dan jumlah anakan produktif) pada masing-masing galur mutan (Tabel 1). From the selection results, there were variations between vegetative variables (plant height, total number of tillers, and number of productive tillers) in each mutant line (Table 1). They were 8 early maturing mutant lines and 5 mutant lines with tall plant + number of tillers. It could be observed that almost all characters had an average of plant height above $100 \mathrm{~cm}$ in the early maturing mutant lines. What was interesting about these mutants was that in addition to their early age, the plant height of the mutants was also ideal. There were three lines that had an average ideal of plant height (below $100 \mathrm{~cm}$ ). There were also some lines indicated the same, for example, line 47, 76, and 68. The ideal plant height ranged from $90 \mathrm{~cm}$ to 100 $\mathrm{cm}$ [7]. The plants that were not ideal were more likely to fall than plants that had ideal height.

Table.1. The average of vegetative variables (plant height, total number of tillers, and number of productive tillers) in early maturing mutants and plant height (TT) of mutants + number of tillers (JA) of Sigah brown rice.

\begin{tabular}{cccc}
\hline \multirow{2}{*}{ Mutant } & \multicolumn{3}{c}{ variabel } \\
\cline { 2 - 4 } & TT $(\mathrm{cm})$ & JAT (tillers) & JAP (tillers) \\
\hline \hline A. Early maturing mutants & & & \\
47 & 96.11 & 13.67 & 13.11 \\
89 & 140.80 & 12.00 & 11.40 \\
53 & 142.00 & 13.18 & 12.64 \\
58 & 126.40 & 20.80 & 20.20 \\
76 & 92.89 & 12.44 & 12.44 \\
111 & 163.92 & 11.23 & 11.08 \\
4 & 109.25 & 15.00 & 15.00 \\
68 & 93.80 & 13.40 & 13.40 \\
76 & & & \\
4 & 88.93 & 25.20 & 25.13 \\
19 & 97.18 & 29.55 & 29.00 \\
68 & 87.27 & 25.67 & 25.33 \\
134 & 94.00 & 26.83 & 26.83 \\
209 & 90.45 & 23.42 & 23.00 \\
26 & 90.00 & 24.50 & 24.00 \\
control & 89.00 & 26.00 & 25.00 \\
\hline
\end{tabular}

Note: TT (plant height), JAT (total number of tillers), JAP (number of productive tillers), JA (number of tillers)

The average total number of tillers in the early maturing mutants was ranged from 10.27 to 15.00 tillers. Meanwhile, the average of productive tillers was ranged from 10.00 to 15.80 tillers. The total number of tillers and productive tillers in line 4 and 68 had the same average score. It could be meant that the total number of tillers in the lines was productive (producing panicles). Whereas, the mutants with tall plant + number of tillers had an ideal plant height ranged from $87.27 \mathrm{~cm}-97.18 \mathrm{~cm}$. The plant 
height and number of tillers obtained were the result of genetic influences on plants.

The total number of tillers and the number of productive tillers in tall plant mutants + the number of tillers from all mutant plant lines had a higher average score compared to control plants (Sigah genotype). The total number of tillers in this mutant line ranged from 23.42 to 29.55 tillers. On the other hand, the number of productive tillers ranged from 23.00 to 29.00 . Of all vegetative variables (plant height, total number of tillers, and number of productive tillers), line 4 was the most attractive mutant line with the ideal plant height and the highest number of tillers. In addition to line 4, line 68 was also attractive with an ideal plant height, the total number of tillers, and the number of productive tillers reached 28.6 points. Thus, all of them were productive tillers. According to [8] (1988), the number of tillers was divided into 3 categories: rich (>15), moderate (10-15), and low (1-10). The visualization of differences in the appearance of each line with control plants can be seen in Appendix 6 .

Moreover, genetic diversity was a quantity that measures the variation in appearance caused by genetic components [9]. The appearance of a plant's phenotype was an interaction between genetic factors and environmental factors. The diversity of phenotypes that appear to be produced by differences in genotype and / or growth environment [10]. But as a result of gamma-ray radiation random mutations that occur in individual plants, cause changes in the appearance of genes in the form of plant traits that can be seen by with bare eyes or not.

On the other side, the estimated score of heritability in a broad sense can be meant as a comparison between total genetic variation and phenotype variety which shows the large proportion of genetic factors in the phenotype of a plant character [11]. The determination of the phenotype diversity, genetic diversity, heritability, variability score, and T-test score on vegetative variables (plant height, total number of tillers, and number of productive tillers) can be seen in Tables 2, 3, and 4 .

The results of vegetative variables of early maturing mutant and tall plant mutants + number of tillers in Table 2 showed that the heritability score for both was still in various categories. They were categorized as high, medium and low. The early maturing mutants with high heritability were found in lines 89, 53, 58, 76, and 68 . Then, the early maturing mutants with moderate heritability (close to high) were found in line 47 , and the early maturing mutants with low heritability score were found in mutants 111 and 4 . Whereas, the variability score of all mutants was almost classified to have wide range tiller diversity, yet there were only some lines classified as narrow range tiller diversity, such as lines 111 and 4 .

Table 2. The variety of phenotypes, genotypes, heritability, and variability of brown rice (M3) with the tall plant mutants variable in vegetative stage

\begin{tabular}{ccccccccc}
\hline Line & Average & $\sigma_{\mathrm{P}}^{2}$ & $\sigma_{\mathrm{G}}^{2}$ & $\mathrm{~h}^{2}$ & category & 2.Sd & var. & T.hitung \\
\hline \hline 47 & $96.11^{*} \pm 10.33$ & 106.61 & 40.44 & 0.38 & Sedang & 20.65 & Luas & 16.93 \\
89 & $153.60^{\mathrm{Tn}} \pm 19.05$ & 362.80 & 296.63 & 0.82 & Tinggi & 38.09 & Luas & 0.25 \\
53 & $142.00^{\mathrm{Tn}} \pm 17.30$ & 299.20 & 233.03 & 0.78 & Tinggi & 34.59 & Luas & 0.39 \\
58 & $126.40^{*} \pm 21.14$ & 447.04 & 380.87 & 0.85 & Tinggi & 42.29 & Luas & 3.14 \\
76 & $92.89^{*} \pm 16.03$ & 256.86 & 190.69 & 0.74 & Tinggi & 32.05 & Luas & 12.02 \\
111 & $163.92^{*} \pm 7.83$ & 61.24 & 4.93 & 0.08 & Rendah & 15.65 & Sempit & 9.08 \\
4 & $109.25^{*} \pm 8.96$ & 80.25 & 14.08 & 0.18 & Rendah & 17.92 & Sempit & 13.90 \\
68 & $93.80^{*} \pm 17.33$ & 300.20 & 234.03 & 0.78 & Tinggi & 34.65 & Luas & 10.95 \\
76 & $88.93^{*} \pm 9.09$ & 82.64 & 16.47 & 0.20 & Rendah & 18.18 & Sempit & 21.80 \\
4 & $97.1 *^{*} \pm 9.77$ & 95.36 & 29.19 & 0.31 & Sedang & 19.53 & Luas & 17.39 \\
19 & $87.27{ }^{*} \pm 4.40$ & 19.35 & 13.83 & 0.71 & Tinggi & 8.80 & Luas & 38.85 \\
68 & $94.00^{*} \pm 10.66$ & 113.60 & 47.43 & 0.42 & Sedang & 21.32 & Luas & 17.18 \\
134 & $90.45{ }^{*} \pm 4.52$ & 20.47 & 14.95 & 0.73 & Tinggi & 9.05 & Luas & 36.03 \\
209 & $90.00{ }^{*} \pm 11.31$ & 128.00 & 61.83 & 0.48 & Sedang & 22.63 & Luas & 17.58 \\
26 & $89.00{ }^{*} \pm 1.41$ & 62.24 & 3.93 & 0.06 & Rendah & 2.83 & Luas & 24.57 \\
\hline
\end{tabular}

Note: *) Significantly different at the 0.05 level according to the T-test; Tn) Not significantly different; $\sigma 2 \mathrm{P}=$ the variety of phenotype $\quad \sim \mathrm{G}=$ the variety of geno ... ; h2 = heritability; $\mathrm{Sd}=$ Standard deviation; , , , , = Early maturing mutants;,,,,$=$ tall plant mutants, number of tillers.

Table.3: The variety of phenotypes, genotypes, heritability, and variability of brown rice (M3) with the total number of tillers in the vegetative stage

\begin{tabular}{|c|c|c|c|c|c|c|c|}
\hline Line & Average & $\sigma_{p}^{2}$ & $\sigma_{G}^{2}$ & $h^{2}$ & category & 2.Sd & var. \\
\hline 47 & $13.67^{\mathrm{Tn}} \pm 4.44$ & 19.75 & 4.08 & 0.21 & Sedang & 8.89 & Sempit \\
\hline 89 & $12.00^{\mathrm{Tn}} \pm 5.10$ & 26.00 & 10.33 & 0.40 & Sedang & 10.20 & Luas \\
\hline 53 & $10.27^{\mathrm{Tn}} \pm 3.23$ & 10.42 & 5.25 & 0.50 & Tinggi & 6.46 & Sempit \\
\hline 58 & $16.40^{*} \pm 5.28$ & 27.84 & 12.17 & 0.44 & Tinggi & 10.55 & Luas \\
\hline 76 & $12.11^{*} \pm 2.67$ & 7.11 & 8.56 & 1,00 & Tinggi & 5.33 & Luas \\
\hline 111 & $11.23^{*} \pm 3.96$ & 15.69 & 0.03 & 0.00 & Rendah & 7.92 & Sempit \\
\hline 4 & $15.00^{\mathrm{Tn}} \pm 2.94$ & 8.67 & 7.00 & 0.81 & Tinggi & 5.89 & Luas \\
\hline 68 & $13.40^{\mathrm{Tn}} \pm 4.28$ & 18.30 & 2.63 & 0.14 & Rendah & 8.56 & Sempit \\
\hline 76 & $25.20^{*} \pm 4.02$ & 16.17 & 0.50 & 0.03 & Rendah & 8.04 & Sempit \\
\hline 4 & $29.55^{*} \pm 5.59$ & 31.27 & 15.61 & 0.50 & Sedang & 11.18 & Luas \\
\hline 19 & $25.67^{*} \pm 7.81$ & 60.95 & 45.29 & 0.74 & Tinggi & 15.61 & Luas \\
\hline 68 & $26.83^{*} \pm 4.22$ & 17.77 & 2.10 & 0.12 & Rendah & 8.43 & Sempit \\
\hline 134 & $23.42^{*} \pm 5.78$ & 33.36 & 17.69 & 0.53 & Tinggi & 11.55 & Luas \\
\hline 209 & $24.50^{*} \pm 3.54$ & 12.50 & 3.17 & 0.25 & Sedang & 7.07 & Sempit \\
\hline 26 & $26.00^{*} \pm 5.66$ & 32.00 & 16.33 & 0.51 & Tinggi & 11.31 & Luas \\
\hline
\end{tabular}

Note: *) Significantly different at the 0.05 level based on the T-test; Tn) Not significantly different; $\sigma 2 \mathrm{P}=$ the variety of phenotypes; $\sigma 2 \mathrm{G}=$ th - ariety of genotypes; h2 'eritability; $\mathrm{Sd}=$ Standard deviation; ", " = Early maturing mutants; , ," ' $=$ tall plant mutants, number of tillers

The tall plant mutants + number of tillers with high heritability score were found in lines 19 and 134 . Whereas, the tall plant mutants + number of tillers with moderate heritability score (almost high) were found in line 47 , and with low heritability score were found in line 
76 and 26. The variability score of all mutants was almost classified to have wide range tiller diversity, yet there was only one line classified as narrow range tiller diversity. It was line 76. The moderate heritability score showed that the environment did not contribute in the character's appearance of the mutants line. Meanwhile, the narrow variability indicated that the characters in the line were varied and they were not effective for further selection.

The vegetative variables result of early maturating mutants and tall plant mutants + number of tillers were observed in the total number of tillers. Table 3 showed that the heritability score of both early maturing and tall plant mutants + number of tillers was still categorized as high, medium, and low. The early maturing mutants with high heritability were found in lines 53, 76, and 4. Next, the mutants with moderate heritability score were in lines 47 , 89 , and 53. Then, the mutants with low heritability score were found in lines 111 and 68. Thus, the tall plant mutants + number of tillers with high heritability were seen in lines 19,134 , and 26 . The mutants with moderate heritability were line 4 and 209. The last, the mutants with low heritability were lines 76 and 68 .

Table.4: The variety of phenotypes, genotypes, heritability, and variability of brown rice (M3) with the number of productive tillers in the vegetative stage

\begin{tabular}{|c|c|c|c|c|c|c|c|}
\hline Line & Average & $\sigma_{\mathrm{p}}^{2}$ & $\sigma_{\mathrm{G}}^{2}$ & $\mathrm{~h}^{2}$ & category & $2 . \mathrm{Sd}$ & var. \\
\hline 47 & $13.11^{\mathrm{Tn}} \pm 4.14$ & 17.11 & 2.25 & 0.13 & Rendah & 8.27 & Sempit \\
\hline 89 & $11.40^{\mathrm{Tn}} \pm 5.27$ & 27.80 & 12.94 & 0.47 & Sedang & 10.55 & Luas \\
\hline 53 & $10.00^{*} \pm 3.58$ & $12.8-$ & 2.06 & 0.16 & Rendah & 7.16 & Sempit \\
\hline 58 & $15.80^{\mathrm{Tn}} \pm 4.92$ & 24.16 & 9.30 & 0.39 & Sedang & 9.83 & Sempit \\
\hline 76 & $11.78^{*} \pm 2.73$ & 7.44 & 7.41 & 1,00 & Tinggi & 5.46 & Luas \\
\hline 111 & $11.08^{*} \pm 4.05$ & 16.41 & 1.55 & 0.09 & Rendah & 8.10 & Sempit \\
\hline 4 & $15.00^{\mathrm{Tn}} \pm 2.94$ & 8.67 & 6.19 & 0.71 & Tinggi & 5.89 & Luas \\
\hline 68 & $13.40^{\mathrm{Tn}} \pm 4.28$ & 18.30 & 3.44 & 0.19 & Rendah & 8.56 & Sempit \\
\hline 76 & $24.80^{*} \pm 3.88$ & 15.03 & 0.17 & 0.01 & Rendah & 7.75 & Sempit \\
\hline 4 & $29.00^{*} \pm 5.10$ & 26.00 & 11.14 & 0.43 & Sedang & 10.20 & Luas \\
\hline 19 & $25.33^{*} \pm 7.39$ & 54.57 & 39.71 & 0.73 & Tinggi & 14.77 & Luas \\
\hline 68 & $26.83^{*} \pm 4.22$ & 17.77 & 2.91 & 0.16 & Rendah & 8.43 & Sempit \\
\hline 134 & $23.00^{*} \pm 5.82$ & 33.82 & 18.96 & 0.56 & Tinggi & 11.63 & Luas \\
\hline 209 & $24.00^{*} \pm 2.83$ & 8.00 & 6.86 & 0.86 & Tinggi & 5.66 & Luas \\
\hline 26 & $25.00^{*} \pm 4.24$ & 18.00 & 3.14 & 0.17 & Rendah & 8.49 & Sempit \\
\hline
\end{tabular}

Note: *) Significantly different at the 0.05 level according to the T-test; Tn) Not significantly different; $\sigma 2 \mathrm{P}=$ the variety of phenotyper $\sim \sim \mathrm{G}=$ the variety of geno _...; $\mathrm{h} 2=$ heritability; $\mathrm{Sd}=$ Standard deviation; , , , , = Early maturing mutants; ,", = tall plant mutants, number of tillers.

The vegetative variables result of early maturing mutants and tall plant mutants + number of tiller were observed in the total number of tillers. Table 4 indicated that the heritability score of both early maturing and tall plant mutants + number of tillers were categorized as high, medium, and low. The early maturing mutant lines with high heritability were line 76 and 4 . Then, the moderate heritability were line 89 and 58. Lastly, the low heritability were lines 47, 53, 111, and 68. The tall plant mutants + number of tillers with high heritability were line 19, 134, and 209. The moderate heritability was line 4 , and the low heritability lines were 76, 68 and 26.

The vegetative variables result of early maturing mutants and tall plant mutants + number of tillers based on the criteria such as plant height parameters, total number of tillers, and the number of productive tillers showed high heritability score. It was proved that the appearance of the characters was influenced by genetic factors. It affected to the ability of these plants to inherit traits in their offspring becoming high. However, it was different with some lines in vegetative variables (plant height, number of tillers, and number of productive tillers) such as the line 111 of early maturing mutants and line 76 of tall plant mutants + number of tillers had low heritability. These results showed that the characteristics of plant height, the total number of tillers, and the number of productive tillers in the line were highly influenced by the environmental factor. On the contrary, the genetic factor did not significantly affected. There was unusual occurrence in line 76. It had more than one heritability. This matter could be caused by an error when the sample was taken. [12] (2011) stated that more than one heritability was biologically impossible. It occurred due to several things; (1) environment differences, (2) inappropriate statistical methods, (3) errors in sampling, and (4) a small number of samples.

Further, the total number of tillers category can also be concluded in some notes. The line 53 of early maturing mutants and the line 209 of tall plant mutants + the number of tillers had high and medium (almost high) heritability or high similarity levels. In this case, the genetic factors affected the character's appearance. Whereas, there was only one line categorized as productive tiller which was line 58. However, the value of genetic diversity of the strains was categorized as narrow. This result showed that genetic diversity in these tillers was considered to be stable and would not change. In fact, the chances of successful breeding were determined by the presence of genes that carry the desired traits and genetic diversity. On the other hand, the genetic diversity was obtained from the diversity of population-forming genotypes and genes that segregate and interact with other genes [13].

\section{CONCLUSION}

It is concluded that based on the selection result there were 8 early maturing mutants and 7 tall plant mutants + number of tillers. The line of early maturing mutants number 89 and 76 had wide diversity range in the 
term of character of plant height, number of tillers, and number of productive tillers in the vegetative phase. Further, the line 4, 19,134 of tall plant mutants + number of tillers have a wide variety of tillers too.

\section{REFERENCES}

[1] Abdullah, B. 2008. Progress of Rice Through Recurrent Selection. J Agron Indonesia, 37 : 188-193

[2] Hayward, M.D., Boseman, N.O., Ramagesa. 1993. Plant Breeding Prospect. Chapman and Hall

[3] Sitaresmi, T., Wening R.H., Rachmi. A.T., Yunani N., Susanto U. 2013. Pemanfaatan Plasma Nutfah Padi Varietas Lokal dalam Perakitan Varietas Unggul. Jurnal Iptek Tanaman Pangan, 8: 22-30

[4] Siwi, B.H., Harahap A. 1977. Present Status of the Indegenous Rice Germ Plasm Collection in Indonesia. Paper presented at the IBPGR/IRRI Rice Genetic Conservation Workshop, 12-15 December, Los Banos, Laguna, Philippines, 17: 17-20

[5] Susanto, U., Daradjat, A.A., Suprihatno B. 2003. Perkembangan Pemuliaan Padi Sawah di Indonesia. Balai Penelitian Tanaman Padi, Sukamandi, Jurnal Litbang Pertanian, 22: 13-27.

[6] G.I. Sadimantara, A.Widarsih, Muhidin, "Seleksi Beberapa Progeni Hasil Persilangan Padi Gogo (Oryza Sativa L) Berdasarkan Karakter Pertumbuhan Tanaman", Jurnal Agroteknos, vol. 3, pp. 48-52, 2013.

[7] Khush, G.S. 2002. Food Security By Design: Improving The Rice Plant In Patnership with NARS. Makalah disampaikan pada Seminar IPTEK Pekan Padi Nasional di Sukarami 2 Maret 2002.

[8] Tirtowiyono, S., Sahi, S., Santika. 1988. Evaluasi Beberapa Galur Harapan Padi Pertanaman Cadangan Transgenik Tahan Wereng Coklat. Badan Pemeliharaan dan Pengembangan Penelitian. Balai Penelitian Tanaman Pangan. Bogor

[9] Rahmadi, M. 2000. Pengantar Pemuliaan Tanaman Membiak Vegetatif, laboratorium pemuliaan tanaman, Fakultas Pertanian Universitas Padjajaran, Bandung

[10] Murti, R.H., Kim, H.Y., Yeoun, Y.R. 2013. Effectiveness of Gamma Ray Irradiation and Ethyl Methane Sulphonate on In Vitro Mutagenesis of Strawberry, Afr. J. Biotechnol, 12: 4803-4812

[11] Fehr, W.R. 1998. Principles of Cultivar Development: Theory and Technique. Mac Millan Publishing Co, 1: 1-12

[12] Rosalina, S. 2011. Keragaman Fenotipe Tanaman Jagung Hasil Persilangan : Studi Heritabilitas Beberapa Sifat Tanaman Jagung [Skripsi]. Universitas Jember. Jember

[13] Efendi, R., Sunarti S., Musa Y., Bdr M.F., Rahim M.D., Azrai M. 2014. Selection of Homozygosity and Genetic Diversity of Maize Inbred using Simple Sequence Repeats (SSRs) marker. Int. J. Curr. Res. Biosci. Plant Biol, 1: 2734 